\title{
ON THE TAXONOMY OF DICRANUM ACUTIFOLIUM AND D. FUSCESCENS COMPLEXES (DICRANACEAE, BRYOPHYTA) IN RUSSIA
}

\section{О ТАКСОНОМИИ КОМПЛЕКСОВ DICRANUМ ACUTIFOLIUM И D. FUSCESCENS (DICRANACEAE, BRYOPHYTA) В РОССИИ}

\author{
DOLGOR YA. TUBANOVA ${ }^{1}$, DENIS V. GORYUNOV ${ }^{2}$, \\ ELENA A. IGNATOVA ${ }^{3} \&$ MICHAEL S. IGNATOV ${ }^{2}$ \\ ДОЛГОР Я. ТУБАНОВА ${ }^{1}$, ДЕНИС В. ГОРЮНОВ ${ }^{2}$, \\ ЕЛЕНА А. ИГНАТОВА ${ }^{3}$, МИХАИЛ С. ИГНАТОВ $^{2}$
}

Abstract

ITS sequences of taxonomically difficult complexes in the genus Dicranum, $D$. fuscescens-D. flexicaule and D. brevifolium-D. acutifolium-D. pseudacutifolium, are analyzed. Type specimens of $D$. pseudacutifolium are found to be poorly developed specimens of $D$. flexicaule and therefore the former name is synonymizedwith the latter. At the same time, several specimens previously identified as D. brevifolium were found to be in a separate clade; they also have morphological differences and are described as a new species, $D$. septentrionale sp. nova.

Резюме

Проанализированы последовательности ITS сложных в систематическом отношении комплексов видов Dicranum fuscescens-D. flexicaule и D. brevifoliumD. acutifolium-D. pseudacutifolium. Показано, что типовые образцы D. pseudacutifolium не отличаются по этому маркеру от $D$. flexicaule и представляют собой, вероятно, не вполне развитые образцы последнего вида. В то же время ряд образцов, уклоняющихся сходным образом в группе D. brevifolium, оказывается четко изолированным генетичски, представляя собой ранее не распознававшийся скрытый вид: D. septentrionale sp. nova.

KEYWORDS: Dicranum, ITS, mosses, new species, new synonym, Russia.

\section{INTRODUCTION}

The genus Dicranum remains a relatively poorly studied group in the Russian moss flora. There are a number of doubtful taxa, as well as specimens whose identification poses a serious difficulties. The application of molecular studies with ITS for the Dicranum viride-group (Ignatova \& Fedosov, 2008) demonstrated that this is a rather promising tool in this genus, as well as in many other moss families.
In the present paper this approach is used to elucidate the status of a recently described species, Dicranum pseudacutifolium Otnyukova (Otnyukova, 2007) and its relationships with the taxa, which are known as a difficult complex of species: D. acutifolium (Lindb. \& Arnell) C.E.O. Jensen, $D$. brevifolium (Lindb.) Lindb., D. flexicaule Brid. and D. fuscescens Turner. The two latter species were not always considered as distinct (cf. Hedenäs \& Bisang, 2004; Ireland, 2007).

1 - Institute of general and experimental Biology of Siberian Branch of Russian Academy of Sciences, Sakhjanovoy str., 6, Ulan-Ude 670047 Russia - Россия 670047 Улан-Удэ, Сахьяновой, д. 6, Институт общей и экспериментальной биологии СО РАН; tdolgor@yandex.ru

2 - Main Botanical Garden of Russian Academy of Sciences, Botanicheskaya 4, Moscow 127276 Russia 127276 Москва, Ботаническая, 4, Главный ботанический сад PAH; denis.goryunov@mail.ru \& misha_ignatov@list.ru

3 - Moscow State University, Biological Faculty, Geobotany Dept., Moscow 119991 Russia - Россия 119991 Москва, Московский государственный университет, Биологический факультет, каф. геоботаники; arctoa@ list.ru 
Table 1. Data on specimens used in phylogenetic analysis and GenBank accession numbers

Species of Dicranum

acutifolium Sakhalin

acutifolium Buryatia

acutifolium NE Yakutia

brevifolium Tuva

brevifolium Karachaevo-Cherkessia

brevifolium North Ossetia

brevifolium South Yakutia

brevifolium / septentrionale

Kamchatka

brevifolium / septentrionale

Arkhangelsk

brevifolium / septentrionale

Putorana

cf. pseudacutifolium / acutifolium

Buryatia

cf. pseudacutifolium / acutifolium

SE Yakutia

cf. pseudacutifolium / acutifolium

NE Yakutia

flexicaule Zabaikalsky

flexicaule Primorsky

flexicaule Komi

fuscescens Perm

fuscescens Sakhalin

fuscescens Sverdlovskaya

fuscescens Primorsky

pseudacutifolium / flexicaule Tuva

pseudacutifolium / flexicaule

Putorana 1

pseudacutifolium / flexicaule

Putorana 2
TCS code Specimen

$\begin{array}{ll}\text { A1 } & \text { Sakhalin, Ignatov \# 06-18 (MHA) } \\ \text { A2 } & \text { Buryatia, Tubanova \# Ok-01/08 (UUH) } \\ \text { A3 } & \text { Yakutia, 26.VII. 2007 Isakova s.n. (MHA) } \\ \text { B4 } & \text { Tuva, 12.VI.2007 Otnyukova s.n. (KRF) } \\ \text { B2 } & \text { Karachaevo-Cherkessia, 27.VII.1996 Egorov s.n. } \\ \text { B3 } & \text { North Ossetia, 6.IX.2002 Korotkov s.n. (MW) } \\ \text { B1 } & \text { Yakutia, 3.VIII.2000 Kuznetzova s.n. (MW) } \\ & \\ \text { S3 } & \text { Kamchatka, 4.VIII.2007 Neshataeva \#986 (LE) } \\ & \\ \text { S1 } & \text { Arkhangelsk Province, Churakova \# } 864(\mathrm{MW}) \\ \text { S2 } & \text { Krasnoyarsk Territory, Putorana, 21.VII.1969 } \\ & \text { Kuvaev \# 46-8 (MW) }\end{array}$

PS1 Buryatia, Tubanova \# Ok-01/08 (UUH)

PS2 Yakutia, Ignatov \# 00-813 (MHA)

PS3 Yakutia, 26.VII. 2007 Isakova s.n. (MHA)

FL1 Zabaikalsky Territory, 4.VIII.2006 Dudareva s.n. (IRK) HQ830331

FL2 Primorsky Territory, Ignatov \# 06-2637 (MHA)

FL3 Komi, 4.VII.2007 Kucherov s.n. (MW)

FU1 Perm Province, 2005 Bezgodov \& Shkaraba s.n. (MHA)

FU2 Sakhalin, Ignatov \# 06-14 (MHA)

FU3 Sverdlovskaya Province, Braslavskaya \# DKT64 (MW)

FU4 Primorsky Territory, Ignatov \# 06-2588 (MHA)

PA3 Tuva, 23.VII.1995 Molokova s.n. (KRF)

PA2 Krasnoyarsk Territory, Putorana, 29.VII.1991

Otnyukova s.n. (MHA)

Isotype of $D$. pseudacutifolium

PA1 Krasnoyarsk Territory, Putorana, 29.VII.1991

Otnyukova s.n. (KRF)

Holotype of D. pseudacutifolium
HQ830325

HQ830326

HQ830327

GenBank \#

HQ830322

HQ830323

HQ830324

HQ830341

HQ830344

HQ830338

HQ830339

HQ830340

HQ830332

HQ830333

HQ830334

HQ830335

HQ830336

HQ830337

HQ830328

HQ830329

HQ830330

DQ294335

scoparium

\section{MATERIAL AND METHODS}

Morphological studies were based on collections from MHA, MW, KRF, UUH, LE, IRK.

Molecular phylogenetic analysis was focused on D. pseudacutifolium, as well as on D. flexicaule and D. fuscescens. Three of 'the most typical' specimens of $D$. acutifolium were included in the study. Seven samples of $D$. brevifolium, which came from distant localities were selected. Preference was given to the morphotypes that somewhat differed from others in cell areolation. Data on voucher specimens and Genbank accession numbers are provided in Table 1. Species names are given as they were identified by morphology.

The protocol of DNA extraction, PCR and sequencing of ITS data were the same as de- scribed by Gardiner et al. (2005). Sequences were aligned manually in BioEdit (Hall, 1999). Parsimony analysis was done with Nona (Goloboff, 1994) within the Winclada shell (Nixon, 1999) and bootstrap support was calculated with 3000 replications (mult*N 10, hold 10, do max). The tree was rooted on Dicranum scoparium.

Haplotype network analysis was performed in TCS 1.21 (Clement et al., 2000), with various parameters discussed below.

\section{RESULTS}

Phylogenetic analysis resulted in a bootstrap tree (Fig. 1) where Dicranum fuscescens, D. flexicaule and three specimens of D. pseudacutifolium (including parts of the isotype and holotype) appeared in the terminal clade. Sister to this ter- 


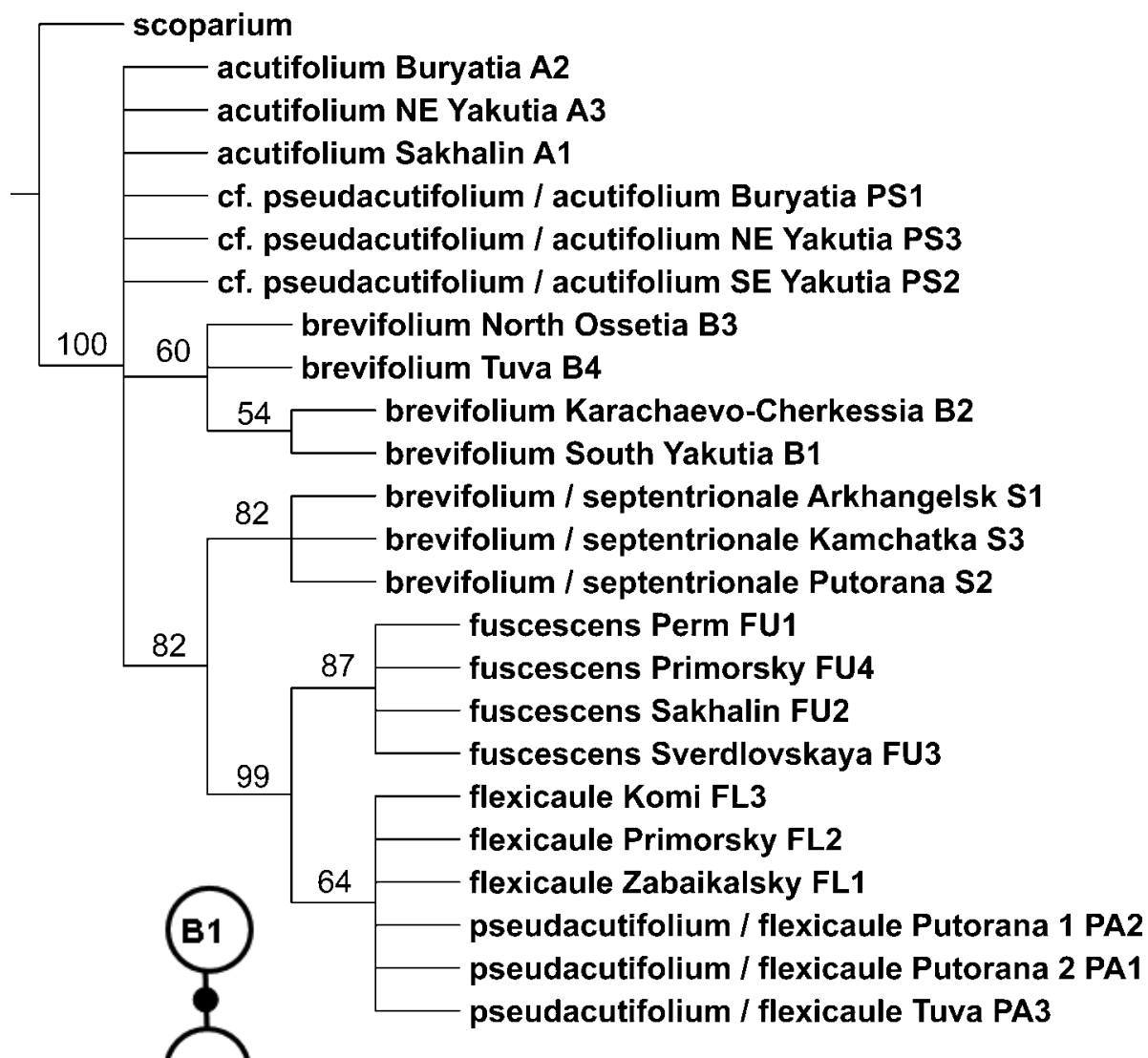

B3

Fig. 1. Bootstrap tree for the species of Dicranum acutifolium and D. fuscescens complexes with D. scoperium as an outgroup Support values $>50$, calculated by 3000 iterations in Nona, are indicated above branches.

B2 B4

A1 A2 A3

PS1 PS2 PS3
Fig. 2. ITS haplotype network for the species of Dicranum acutifolium and D. fuscescens complexes. For abbreviations see Table 1 and Fig. 1. 
minal clade is a clade formed by three northern specimens of D. brevifolium. Basal polytomy includes Dicranum acutifolium, three specimens identified as $D$. cf. pseudacutifolium, and a clade of four specimens of $D$. brevifolium.

Bootstrap support was found to be high for the whole terminal clade formed by $D$. flexicaule, $D$. pseudacutifolium and D. fuscescens (99) and within it also for the clade of D. fuscescens (87). The clade of $D$. flexicaule and $D$. pseudacutifolium was low supported (64), despite the fact that the visual analysis of the alignment found not one parsimony informative substitution within this group of 6 specimens. Also, the high bootstrap value (82) was found for the clade of three northern specimens of $D$. brevifolium.

TCS analysis with a connection limit at 12 steps $(94 \%)$, with the gap as missing data and no gap coding resulting in a haplotype network (Fig. 2), shows delimited groups in a certain way similar to that in the phylogenetic tree in Fig. 1. The gap coding as a singular event regardless of gap length (not shown), gave the subidentical network that differs mainly in larger numbers of missing haplotypes between taxa, up to 20 between $D$. flexicaule and D. acutifolium.

The TCS analysis shows the position in the same haplotype for $D$. flexicaule and D. pseudacutifolium (type and Tuva specimens), as well as for D. acutifolium and $D$. cf. pseudacutifolium (one of specimens of $D$. acutifolium has one insertion of one adenine nucleotide, which separates it in the analysis with the second variant of gap coding).

\section{DISCUSSION}

The present analysis confirms neither the separate position of the type specimens of the $D i$ cranum pseudacutifolium from the earlier described and widespread $D$. flexicaule, nor the homogeneity of the former species. Specimens identified as D. pseudacutifolium are found in two clades, together with $D$. flexicaule and with $D$. acutifoli$u m$, the species which were considered the most similar to $D$. pseudacutifolium by Otnyukova (1.c.).

\section{Dicranum pseudacutifolium and D. flexicaule}

According to the original description, the distinctions of $D$. pseudacutifolium from D. flexicaule include straight and thin lamina cell walls vs. "not straight" and thick lamina cell walls (which is not always so in D. flexicaule, accor- ding to our observations). Also, included are leaves "keeled-channeled, looking like a pair of tongs in leaf cross section" vs. "keeled-tubulose" in D. flexicaule. However, the illustrations of the holotype by Otnyukova (1.c.) are variable for the latter character, showing both patterns. Other distinguishing characters listed in the table are numerous and still more variable so that any of them may occur in D. flexicaule.

Although the clade formed by three specimens of D. pseudacutifolium and three of D. flexicaule has only moderate support (64, cf. Fig. 1), the lack of genetic difference (cf. Fig. 2), indicates that by ITS these six specimens are more similar to each other, than e.g. D. flexicaule to $D$. fuscescens. Two latter species consistently differ in two substitutions, despite (1) D. flexicaule and D. fuscescens are often considered to be very closely related and sometimes treated as infraspecific taxa of one species; (2) both species were represented in analysis by specimens from European Russia and Russian Far East, with the distance between the localities over $5000 \mathrm{~km}$.

The analysis of morphology indicates that the type of D. pseudacutifolium was selected among not very typical plants of $D$. flexicaule with quite thin cell walls and less falcate leaves. Therefore D. pseudacutifolium is synonymized here with D. flexicaule. A similar variation in these characters occurs in many species of Dicranum, especially in the severe climate in Siberia.

The problem, however, should not be oversimplified, as the part of the specimens identified originally as $D$. pseudacutifolium (called here as $D$. cf. pseudacutifolium) were found within the basal polytomy formed by $D$. acutifolium. These specimens, i.e. D. cf. pseudacutifolium, are morphologically more similar to the plants of the type of $D$. pseudacutifolium than to 'typical' D. acutifolium, which was revealed to be its closest relative by ITS data (Figs. 3-7).

Our attempts to find any stable discriminative morphological character or combination of characters between $D$. pseudacutifolium and $D$. cf. pseudacutifolium were not successful. A number of herbarium specimens (especially from the Eastern Siberia) were left with a question mark since we were not able to decide if they belong to thin-walled $D$. flexicaule (i.e. like the type of $D$. pseudacutifolium) or to D. cf. pseudacutifolium. At the same time (as discussed below), there is a 

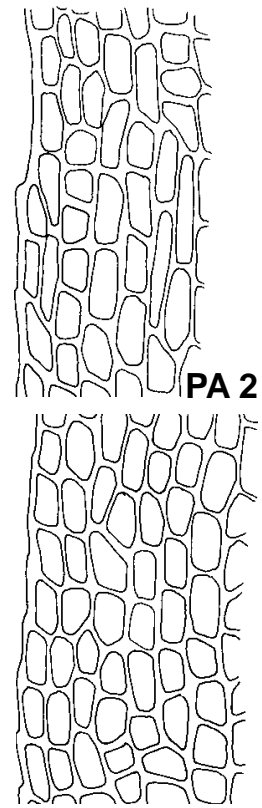

PA 3

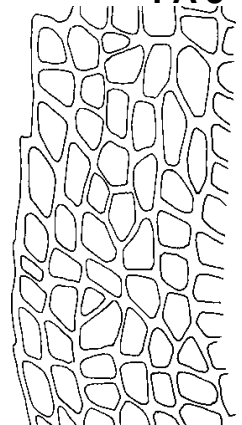

FL 1

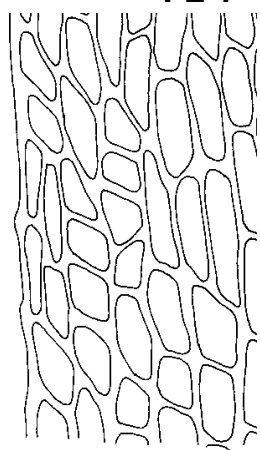

FL 2

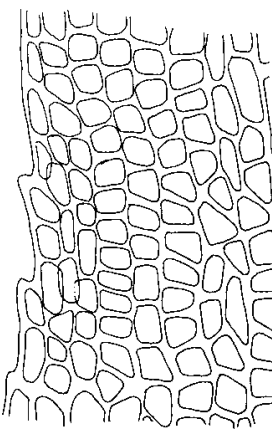

PS 1
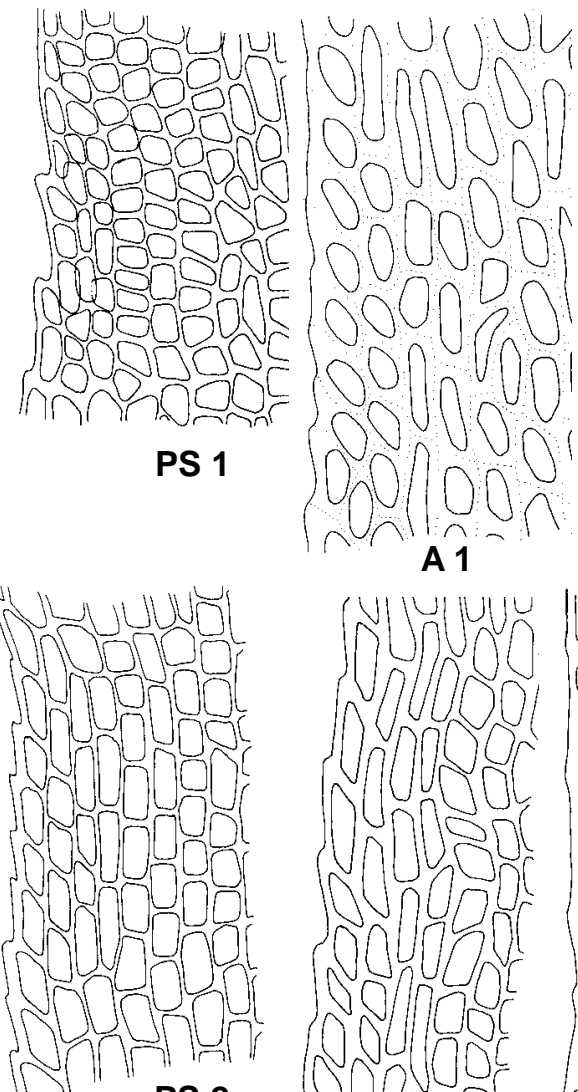

PS 2

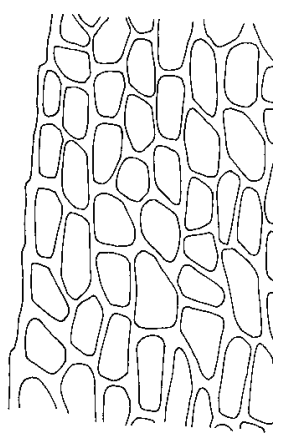

PS 3
A 1

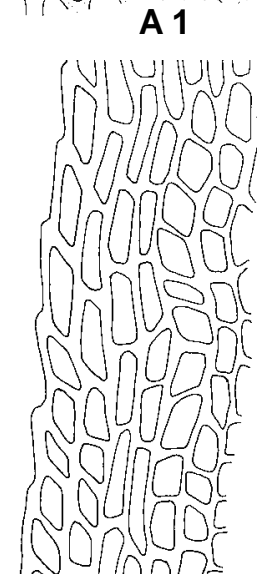

A 2
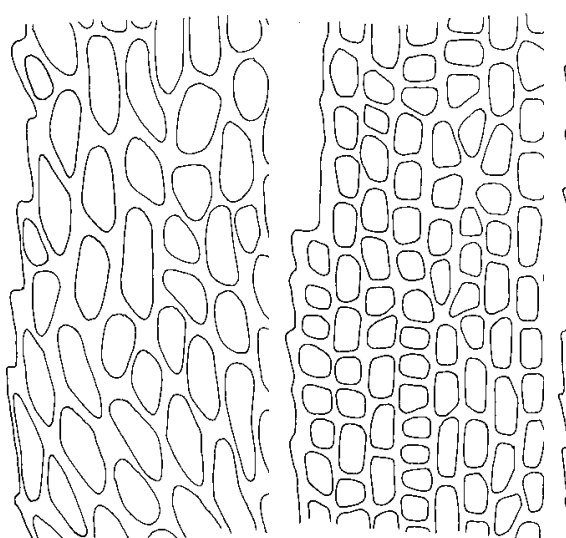

S 3

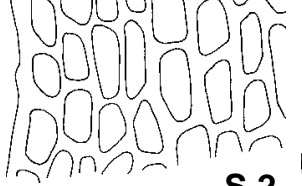

S 2

A 3

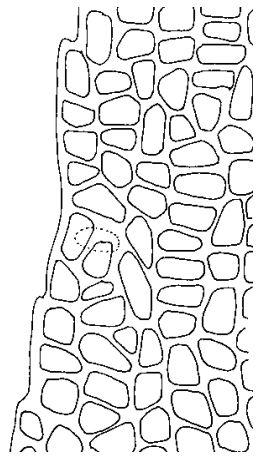

B 1

\section{S 1}

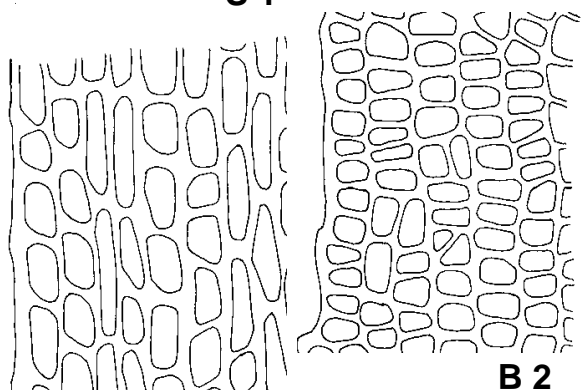

B 2

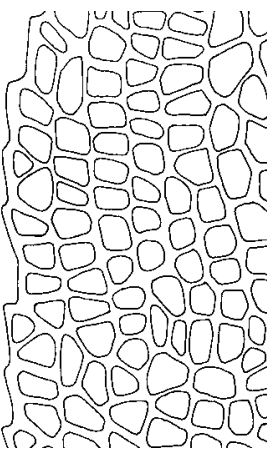

B 3

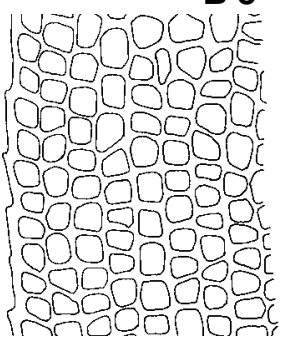

Fig. 3. Upper leaf cells. For abbreviations see Table 1 and Fig. 1.

B 4

certain difference in morphology between $D$. cf. pseudacutifolium and D. acutifolium.

\section{Dicranum pseudacutifolium and $D$. acutifolium}

According to the original description, Dicranum pseudacutifolium differs from $D$. acutifoli- um primarily in the absence of bulges between the cell walls as it is seen in leaf cross sections (Otnyukova, 1.c.). However, many authors describe this character in $D$. acutifolium as very variable and there is also an inconsistence among authors in this respect, e.g. Hedenäs \& Bisang 


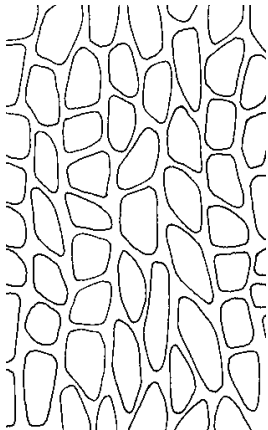

PA 2

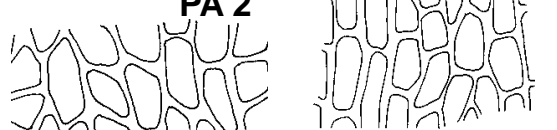

PS 1
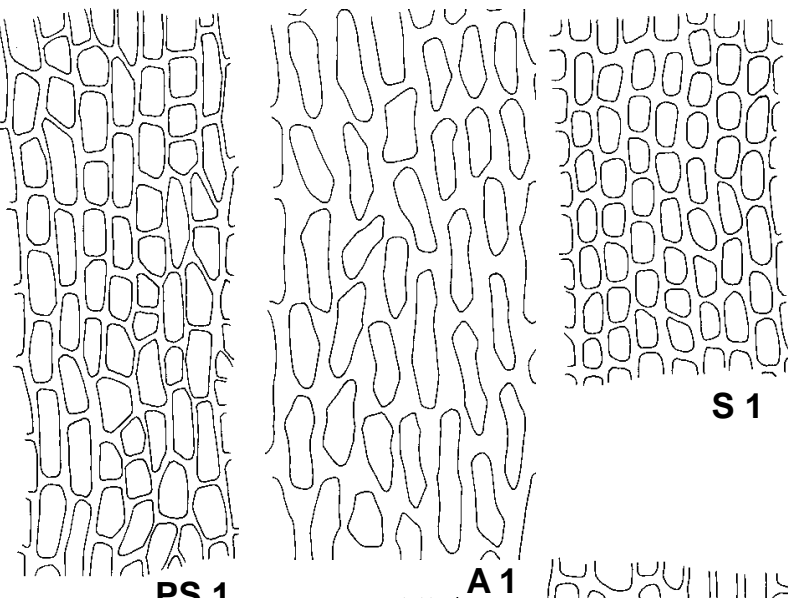

s 1

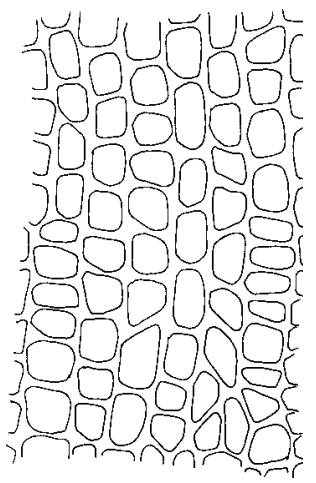

B 1
B 2

S 2

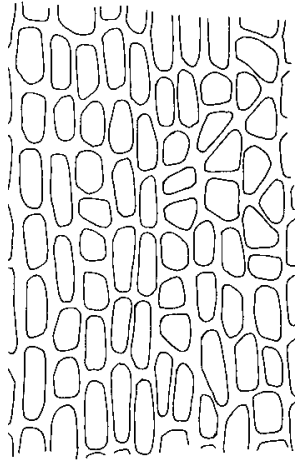

17
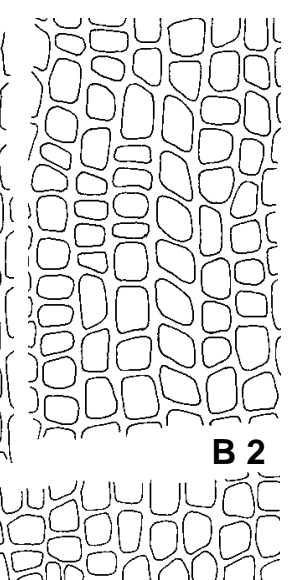

A 2
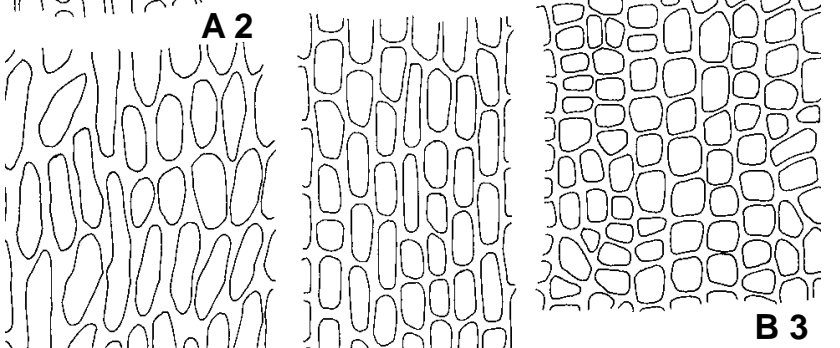

B 3

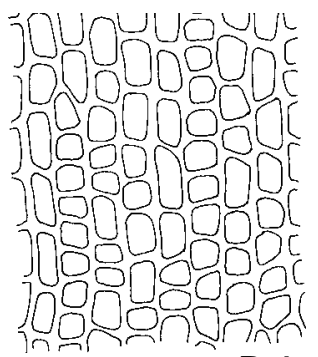

B 4 (l.c.) reported their presence, while Ireland (1.c.) reported cell walls of D. acutifolium to be smooth or slightly bulging. Our observation found mostly very weak to completely absent bulgings in $D$. acutifolium in most of Siberian specimens, thus this character may hardly be considered of a great importance. In all sequenced specimens of the latter species these bulges are weak to almost absent (Fig. 7: A1-3), while other diagnostic characters of D. acutifolium, i. e. thick-walled and 

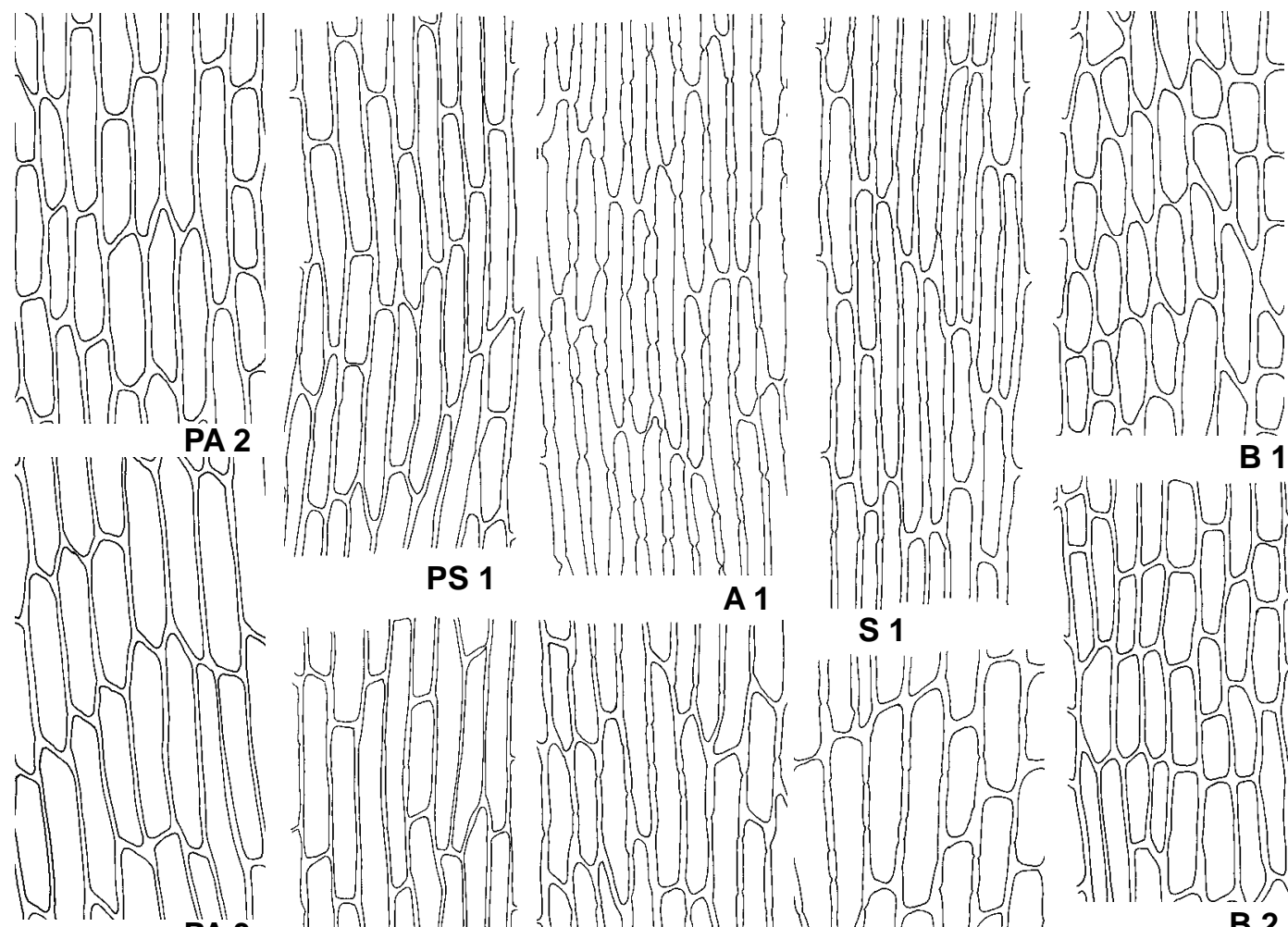

PS 1
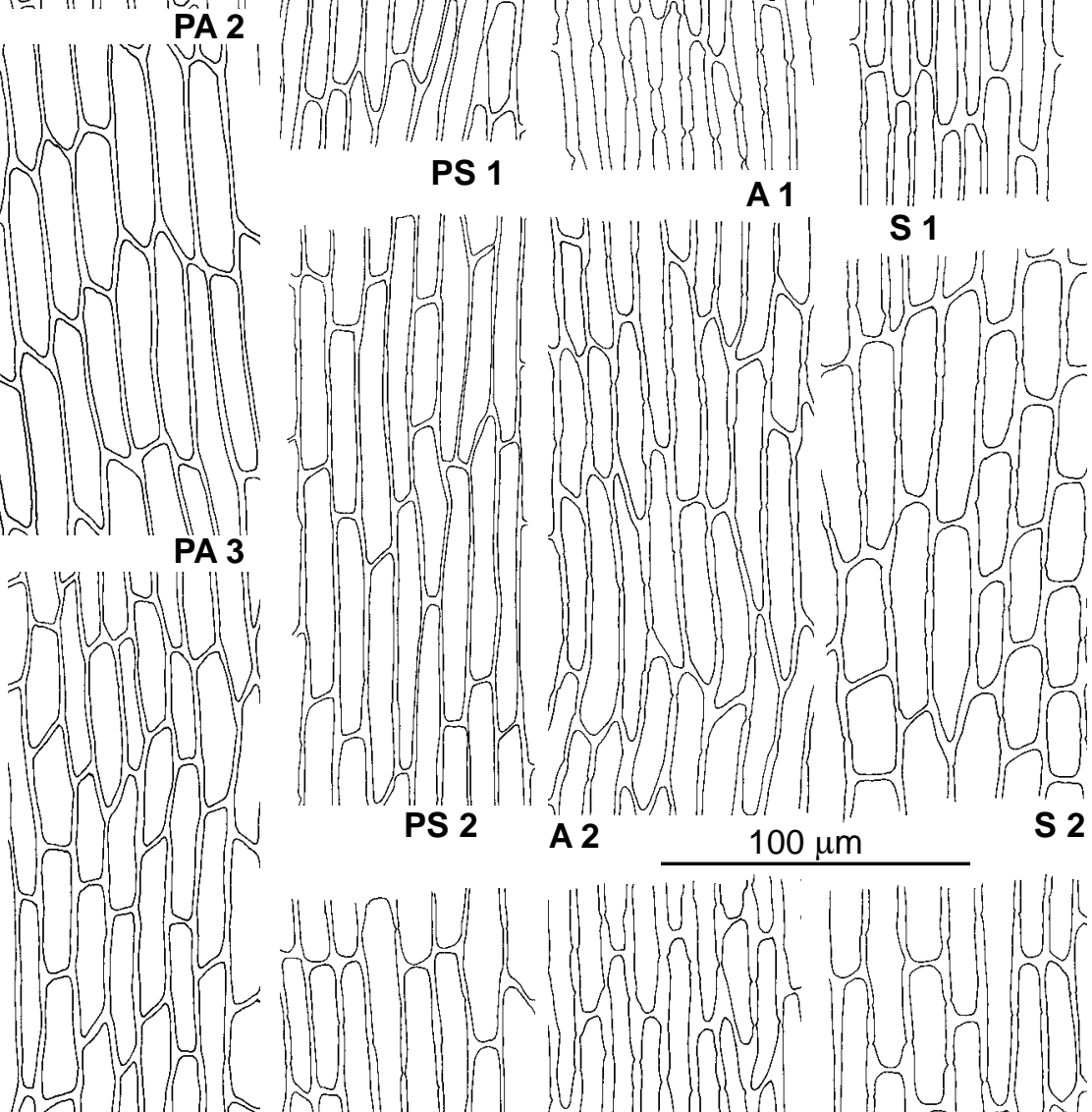

PS 2
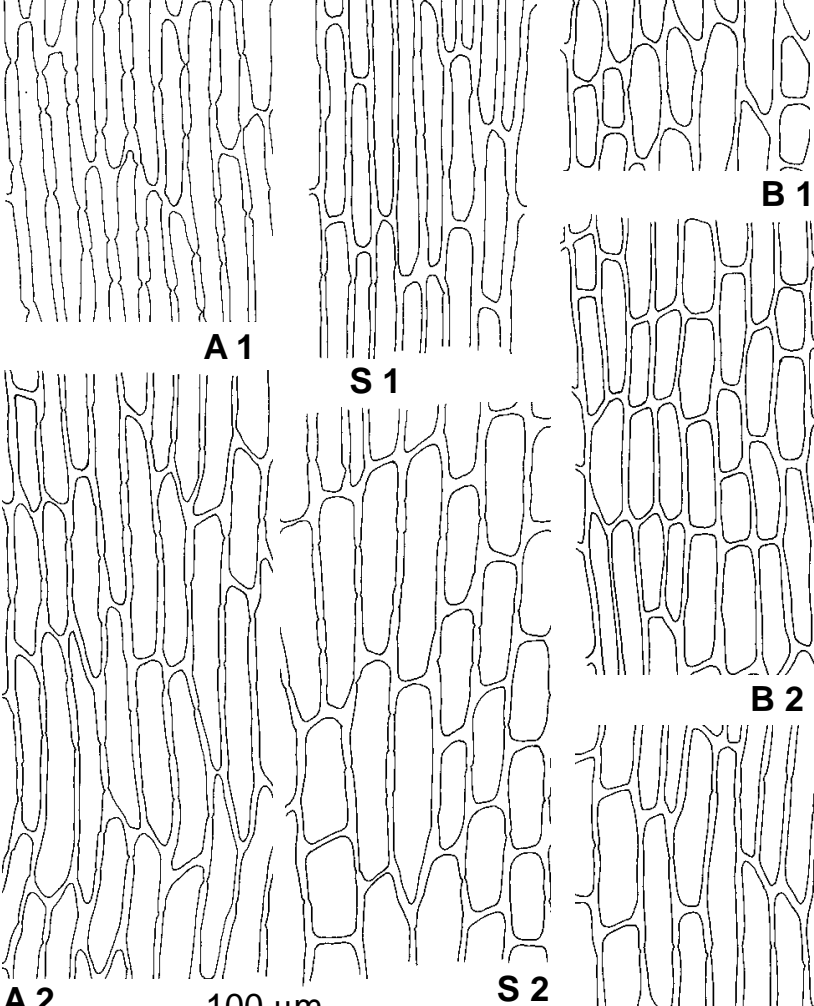

B 1
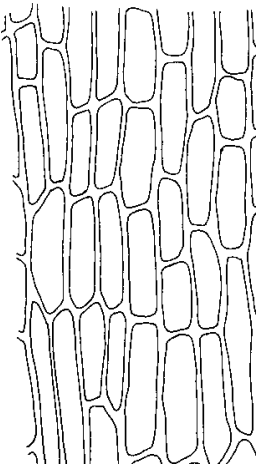

\section{B 2}

$74\|v\|$
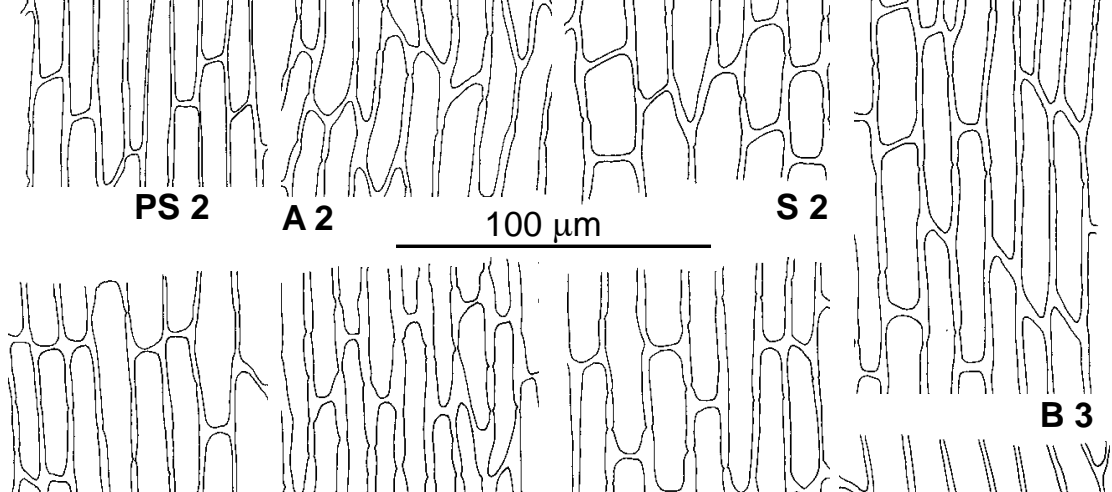

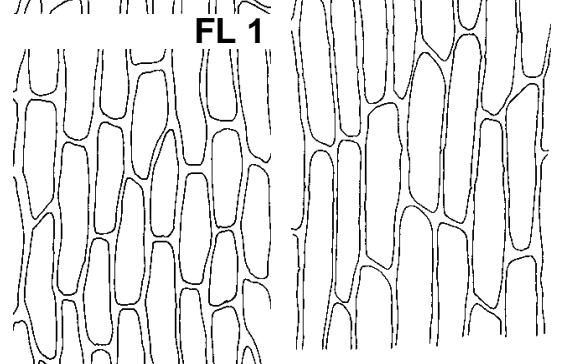

N N

14 Minition
PS 3

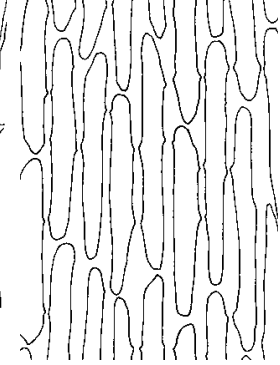

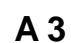

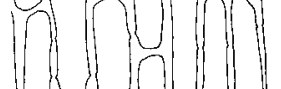

B 3

FL 2 Fig. 5. Basal leaf cells. For abbreviations see Table 1 and Fig. 1.

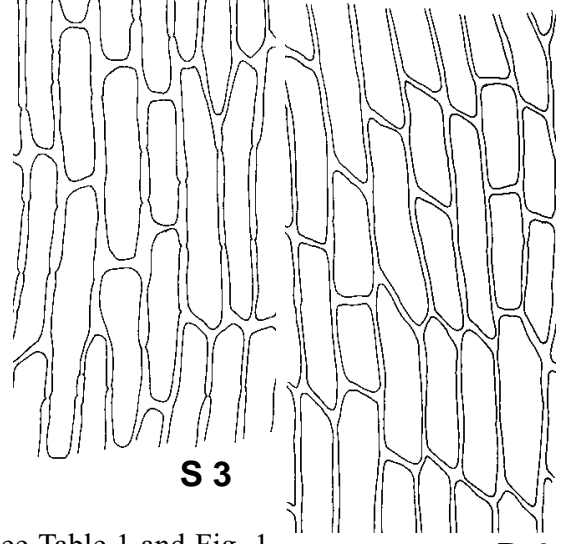




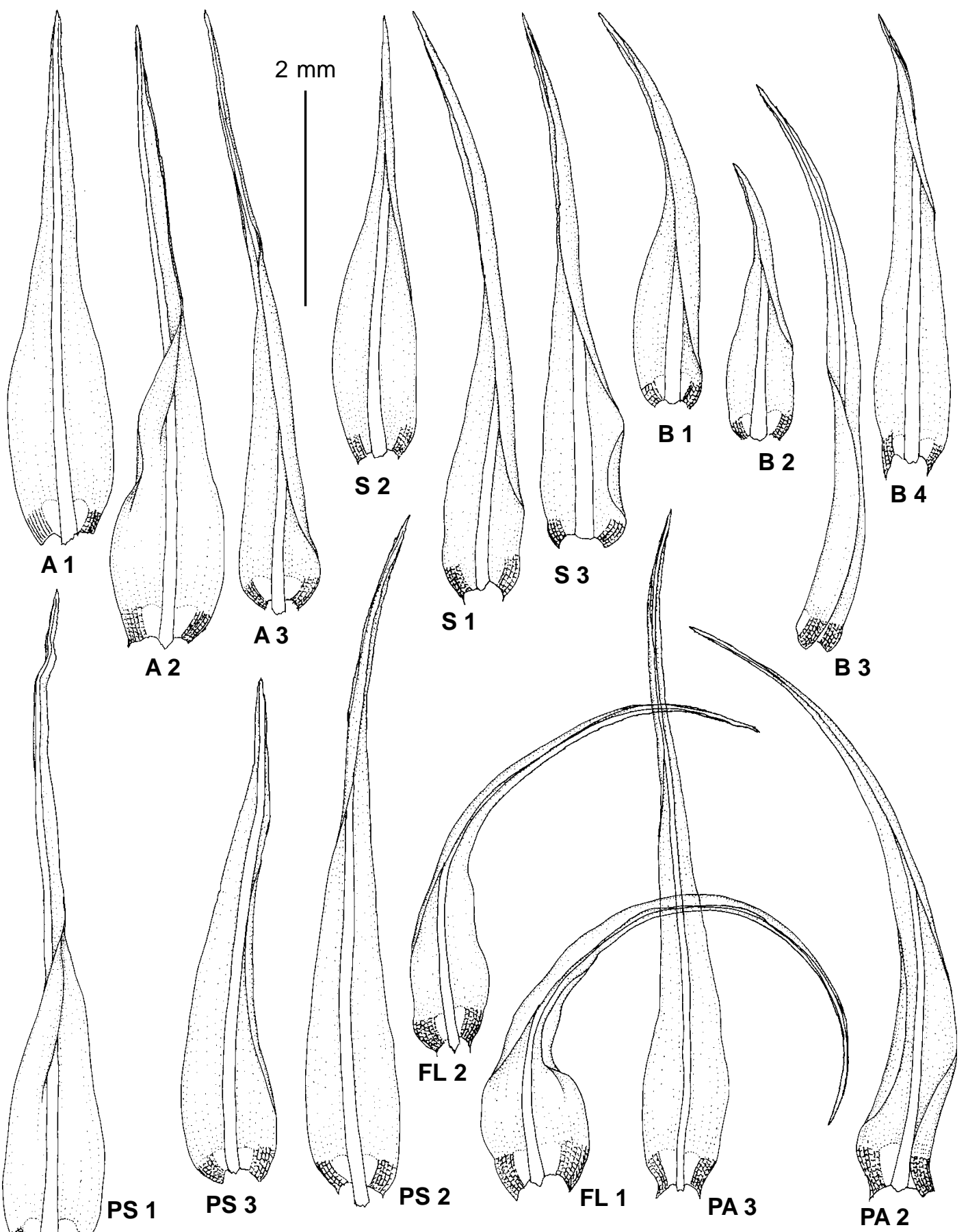

Fig. 6. Leaves. For abbreviations see Table 1 and Fig. 1.

irregularly shaped distal lamina cells and long, porose proximal cells, are more important for their identification (Figs. 3-5: A1-3).

Three specimens of $D$. cf. pseudacutifolium that appeared in the basal polytomy with $D$. acuti- folium and D. brevifolium (in part) are rather distinct in cell areolation. They differ from two specimens of D. acutifolium (Figs. 3-4: A1, 3) in the contrastingly thin-walled distal lamina cells, mostly arranged in clear longitudinal rows ver- 
sus the usually strongly thickened and irregular cells in D. acutifolium; although in one specimen (Figs. 3-4: A2) these characters have intermediate states.

The basal lamina cells are similar in shape in D. cf. pseudacutifolium and D. acutifolium, but in the former they are relatively thin-walled and weakly porose (Fig. 5 PS1-3), in contrast to the usually thick-walled and strongly porose basal cells in D. acutifolium (Fig. 5 A1 \& A3, but not A2, which is intermediate).

Leaf shape is similar in $D$. cf. pseudacutifolium and $D$. acutifolium, with at best the only small difference. Specimens of $D$. cf. pseudacutifolium with longer leaves are somewhat curled when dry. Also all leaves have a distinct group of thin-walled, hyaline cells between alar region and costa.

The differences between $D$. cf. pseudacutifolium and D. acutifolium in areolation may be taxonomically significant, but an additional study is needed to confirm that the former is not just a marginal phenotype within the range of $D$. acutifolium. Before this possible formal recognition, we have chosen to keep the plants of $D$. cf. pseudacutifolium within $D$. acutifolium.

\section{Dicranum flexicaule and D. fuscescens}

These two species are considered to be hardly separable from each other due to the numerous specimens with intermediate characters, which are impossible to determine for certain. Hedenäs \& Bisang (1.c.) express a doubt if they are really a good species, even if their extreme phenotypes are readily recognizable. BellolioTrucco \& Ireland (1990) and Ireland (1.c.) treat $D$. flexicaule as a variety of $D$. fuscescens. Among differential characters of these species are usually listed: 1) densely and coarsely denticulate distal leaf margins of $D$. fuscescens vs. irregularly denticulate, with long entire portions to almost entire ones of $D$. flexicaule; 2 ) upper lamina cells relatively regularly quadrate, frequently mamillose vs. irregular in shape, only with scattered mamillae; 3) costa dorsally densely denticulate or rough in upper $2 / 5-4 / 5$ of the costa vs. relatively distantly denticulate or rough in the upper 1/3 (Hedenäs \& Bisang, 1.c.); Ireland (2007) describes the costa as almost smooth on dorsal surface in var. flexicaule and adds that the length of seta is longer than $2.5 \mathrm{~cm}$ vs. less than $2.5 \mathrm{~cm}$ in var. fuscescens. Savicz-Lyubitzskaya \& Smirnova (1970) and Ignatov \& Ignatova (2003) also mention the costa width, which is less strong in D. flexicaule, $1 / 10-1 / 7$ vs. $1 / 7-1 / 5$ the width of the leaf base in D. fuscescens.

Specimens used in the present analysis represent rather typical phenotypes of both species, except specimen of D. flexicaule FL1, Zabaikalsky Territory, which is similar to $D$. fuscescens habitually and in strongly rough costa in the distal half or more, and upper lamina cells densely mamillose distally. However, its leaf margins are strongly serrate only along a short distance near apex and below are quite slightly serrulate; distal lamina cells are thin-walled, rather regular but short rectangular (not quadrate); costa is narrow, ca. 1/10 the width of leaf base. In ITS1-2 this specimen does not differ from other specimens of $D$. flexicaule.

The analysis of ITS sequences of $D$. fuscescens and $D$. flexicaule found only two substitutions between them (Fig. 2), but this difference remains stable in a broad geographical range and consistenly associated with morphology. Therefore the species status of $D$. flexicaule is more likely than just an infraspecific entity within D. fuscescens.

\section{Dicranum brevifolium and $D$. septentrionale, sp. nov.}

Seven specimens of $D$. brevifolium included in the analysis were resolved in two clades, one having a high bootstrap value (82), while another one was quite weakly supported (60). The former (group 1) is situated in a grade to D. fuscescens- $D$. flexicaule terminal clade, while the latter (group 2) appeared in an unresolved grade with D. acutifolium (Fig. 1).

Originally all these plants were identified as D. brevifolium because they have more or less strongly crispate leaves in dry condition, distal lamina cells are arranged in clear longitudinal rows, distal lamina cells are moderately thickwalled and have distinct bulgings upon longitudinal walls as it is seen in a leaf transverse section.

However, plants have also a number of characters specific for each of these two clades. Plants of the group 1 have mostly rectangular cells in distal and median lamina vs. predominantly isodiametric and transversely rectangular in group 2 . The basal lamina cells are longer, (2.5-)4-6(-10):1 and clearly porose in group 1 vs. comparatively 

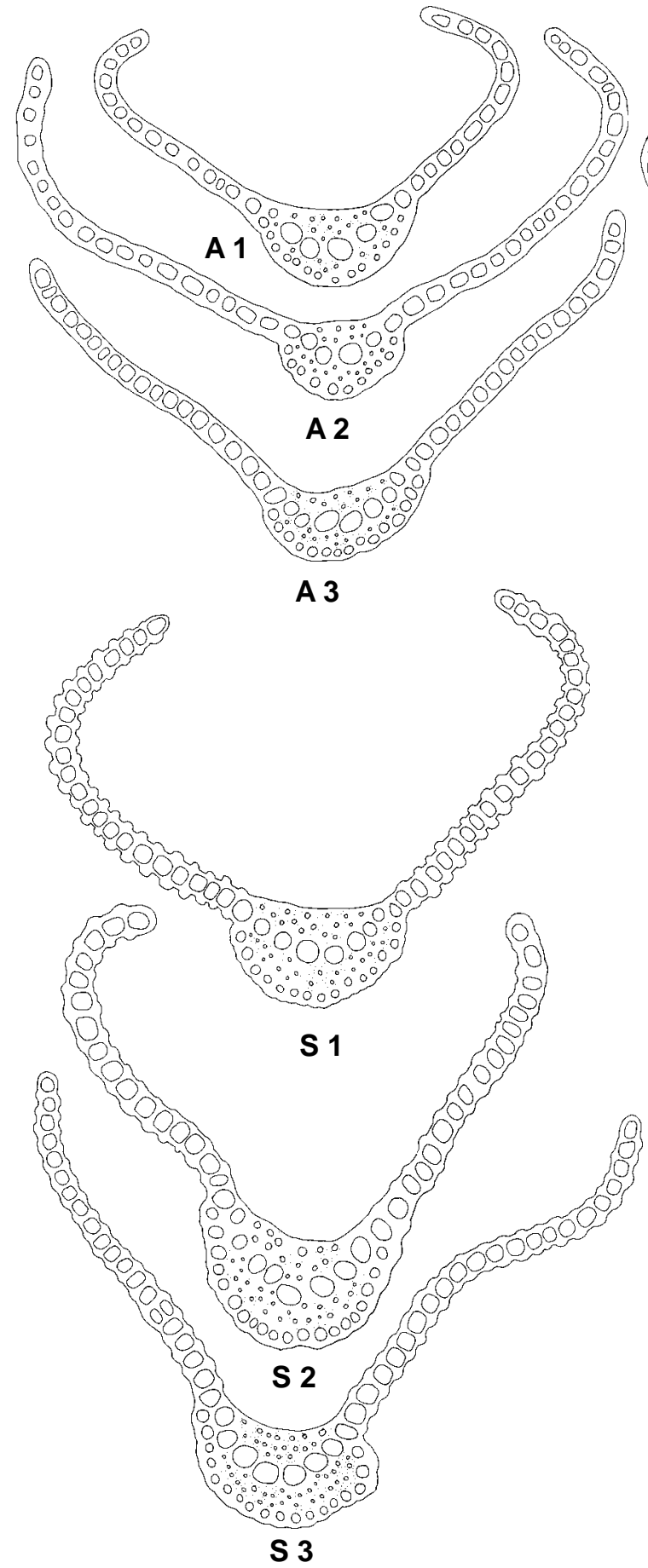

Fig. 7. (cf. also Fig. 7a on opposite page) Transverse leaf sections. For abbreviations see Table 1 and Fig. 1.

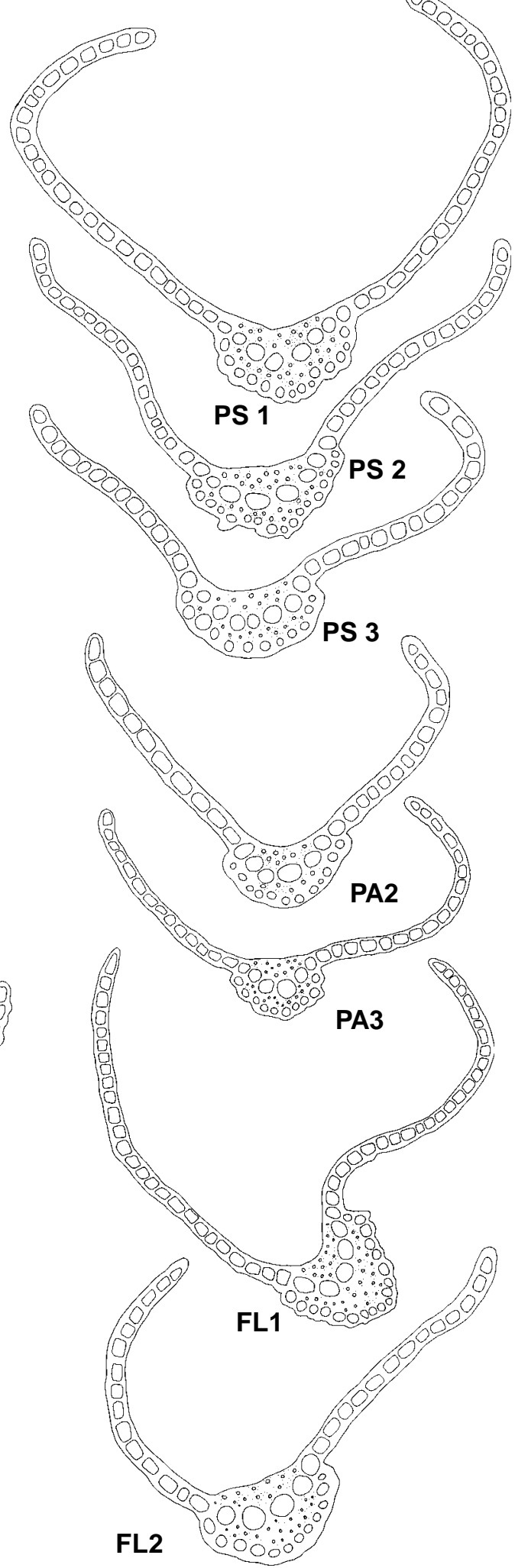




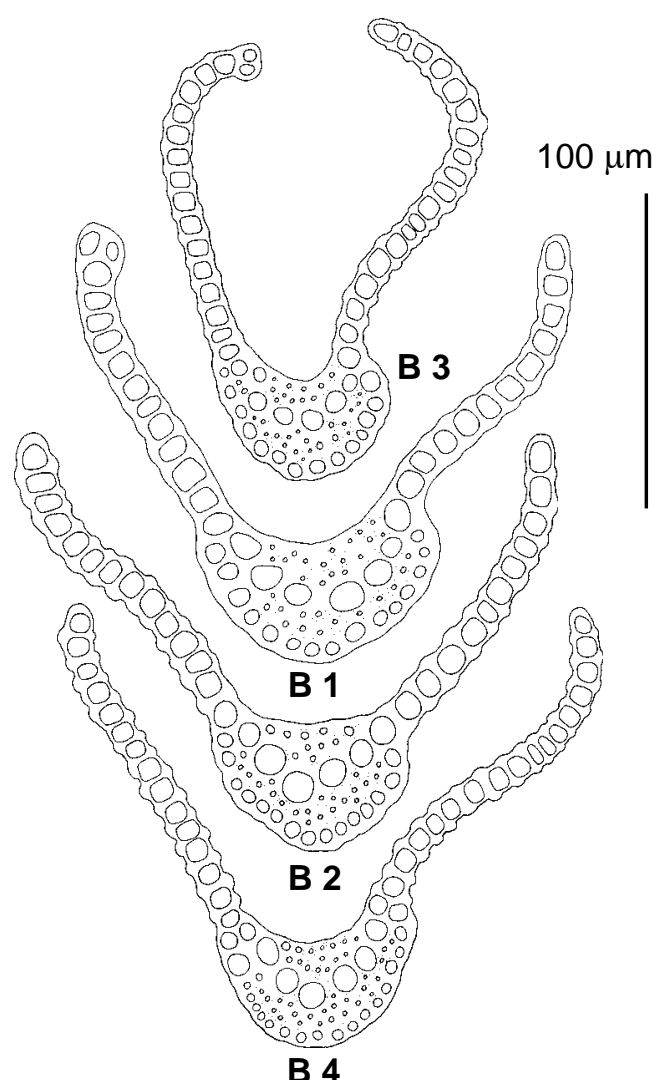

Fig. 7a (cf. opposite page). Transverse leaf sections. For abbreviations see Table 1 and Fig. 1.

short, (1.6-)3-4(-8):1 and not or very slightly porose in group 2. Basal lamina cells are not sharply delimited from rectangular median cells in group 1 vs. contrastingly differ from more opaque quadrate median cells in group 2. Leaves of group 2 have distinct thin-walled hyaline cells between alars and costa, while this is not always the case in group 1. Plants of group 2 fit well the description of $D$. brevifolium and agree with the holotype in all essential characters (Fig. 8 and Figs. 3-7: B1-4). Therefore the name D. brevifolium should be applied to the group 2 in our study, while the group 1 needs to be described as a new species, D. septentrionale (see below).

Though $D$. acutifolium and D. brevifolium have very weak difference in ITS, morphologically these species are quite distinct. Their differentiating characters include: 1) almost straight or slightly flexuose when dry leaves, not secund when moist in D. acutifolium vs. \pm strongly curled when dry leaves, usually secund when moist in $D$. brevi- folium; 2) distal lamina cells irregular in shape, mostly elongate, usually strongly thick-walled, not arranged in longitudinal rows vs. predominantly isodiametric, \pm quadrate, moderately thick-walled cells in clear longitudinal rows; 3) longitudinal cell walls not or weakly bulging vs. clearly, occasionally conspicuously bulging; 4) basal lamina cells (3.5-)5-7(-10): 1 and clearly porose vs. (1.6-) $3-4(-8): 1$ and not or very slightly porose.

In addition to morphology, D. acutifolium and D. brevifolium have a rather contrasting distribution. Dicranum acutifolium is an arctic-alpine species, and it is more common in northern territories including Subarctic and Arctic in Russia; $D$. brevifolium, as appeared after a revision of collections in MW, MHA, LE and UUH, occurs in NW European Russia, Caucasus, South Siberia, and in Yakutia (only in southern part). There are many records of D. brevifolium from the Arctic and Subarctic in Russia (e.g. Ignatov et al., 2006), but at least most of them must be excluded from $D$. brevifolium and put in D. septentrionale.

Dicranum septentrionale Tubanova \& Ignatova sp. nov.

Type: Russia, Arkhangelsk Province, Pinega Nature reserve, 19.VII.2000, Churakova \#864. (Holotype MW, Isotype in MHA. Figs. 3-7 (S1-3), 9.

A D. brevifolio affinis, sed cellulis folii superiorius et mediocrius rectangularibus et cellulis basilibus valde elongates et porosis differt.

Plants medium-sized, in dense tufts, dull yellowish green in upper part, dull brownish below. Stems $5-7 \mathrm{~cm}$, densely tomentose almost to apex, rhizoids of tomentum reddish brown. Leaves curled when dry, falcate-secund when moist, occasionally slightly undulate distally, lanceolate, narrowly acute, 4-6 mm long, 0.7$0.8 \mathrm{~mm}$ wide at base, concave proximally, keeled distally, with incurved margins, in transverse section like a pair of tongs; costa strong, occupies ca. 1/5 the width of leaf base, 150-200 $\mu \mathrm{m}$ wide at base, strongly projecting dorsally in distal part, weakly roughened dorsally in distal $1 / 3$ $(-1 / 2)$ to smooth, with one row of guide cells, two thick stereid bands extending to almost the apex, adaxial epidermal cells not differentiated, abaxial epidermal layer differentiated; margins entire in proximal $1 / 3-1 / 2$, serrulate distally and more strongly serrate near apex, occasion- 


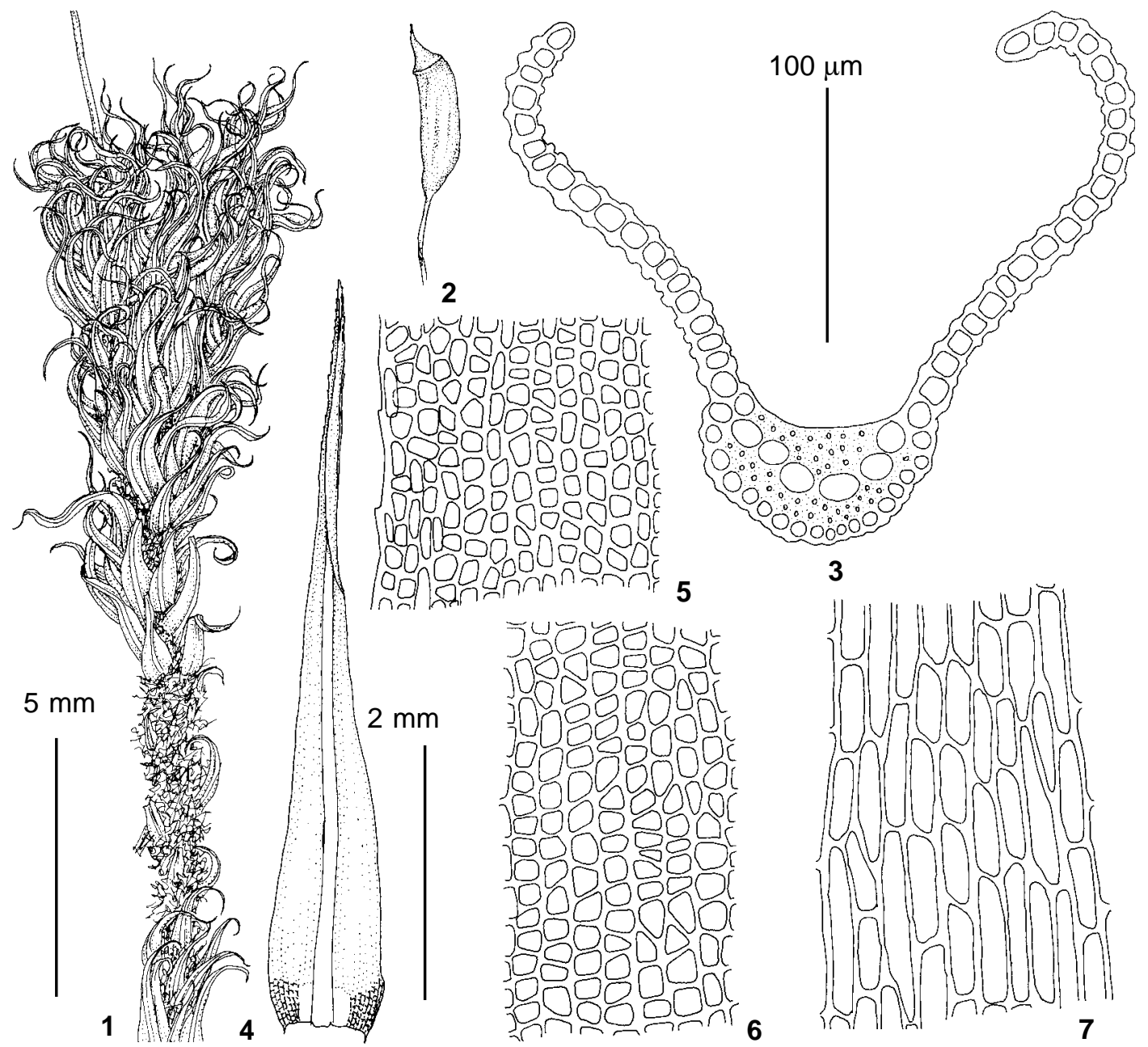

Fig. 8. Dicranum brevifolium (from holotype: Norvegia, N.M.Blytt, H-SOL \#667026); 1 - habit, dry; 2 - capsule; 3 - leaf transverse section; 4 - leaf; 5 - upper lamina cells; 6 - median lamina cells; 7 - basal lamina cells. Scale bars: $5 \mathrm{~mm}$ for $1-2 ; 2 \mathrm{~mm}$ for $4 ; 100 \mu \mathrm{m}$ for 3, 5-7.

ally almost entire; lamina unistratose or occasionally bistratose at places at margins distally and with few bistratose patches near costa; distal lamina cells short-rectangular or elongate rhomboidal with small admixture of isodiametric cells, (7-)10-25×10-12 $\mu \mathrm{m}$, moderately thick-walled, not porose, arranged in clear longitudinal rows, with bulging longitudinal walls, occasionally papillaelike in transverse section; median lamina cells similar to distal cells, $10-30 \times 10(-12) \mu \mathrm{m}$; basal lamina cells long rectangular, (2.5-)4-6(-10):1, 40-100×(8-) 11-14(-16) $\mu \mathrm{m}$, with small admixture of shorter cells, \pm strongly porose; alar cells bistratose, dark brown, cells between alar group and costa shortrectangular, comparatively thin-walled, light brownish or few cells hyaline, occasionally not differentiated from basal lamina cells.

Apparently dioicous; sporophytes very rare; male plants not seen. Sporophytes single in perichaetium; capsules inclined; spores 20-25 $\mu \mathrm{m}$.

Differentiaton. Dicranum septentrionale resembles $D$. acutifolium in areolation due to mostly elongate, rather irregular distal and median lamina cells and long, porose basal lamina cells. However, upper cells of the former species are arranged in longitudinal rows which is uncommon for $D$. acutifolium, and usually moderately to strongly bulging longitudinal cell walls vs. mostly plane or indistinctly bulging cell walls also separate these species. In addition, leaves of $D$. sep- 


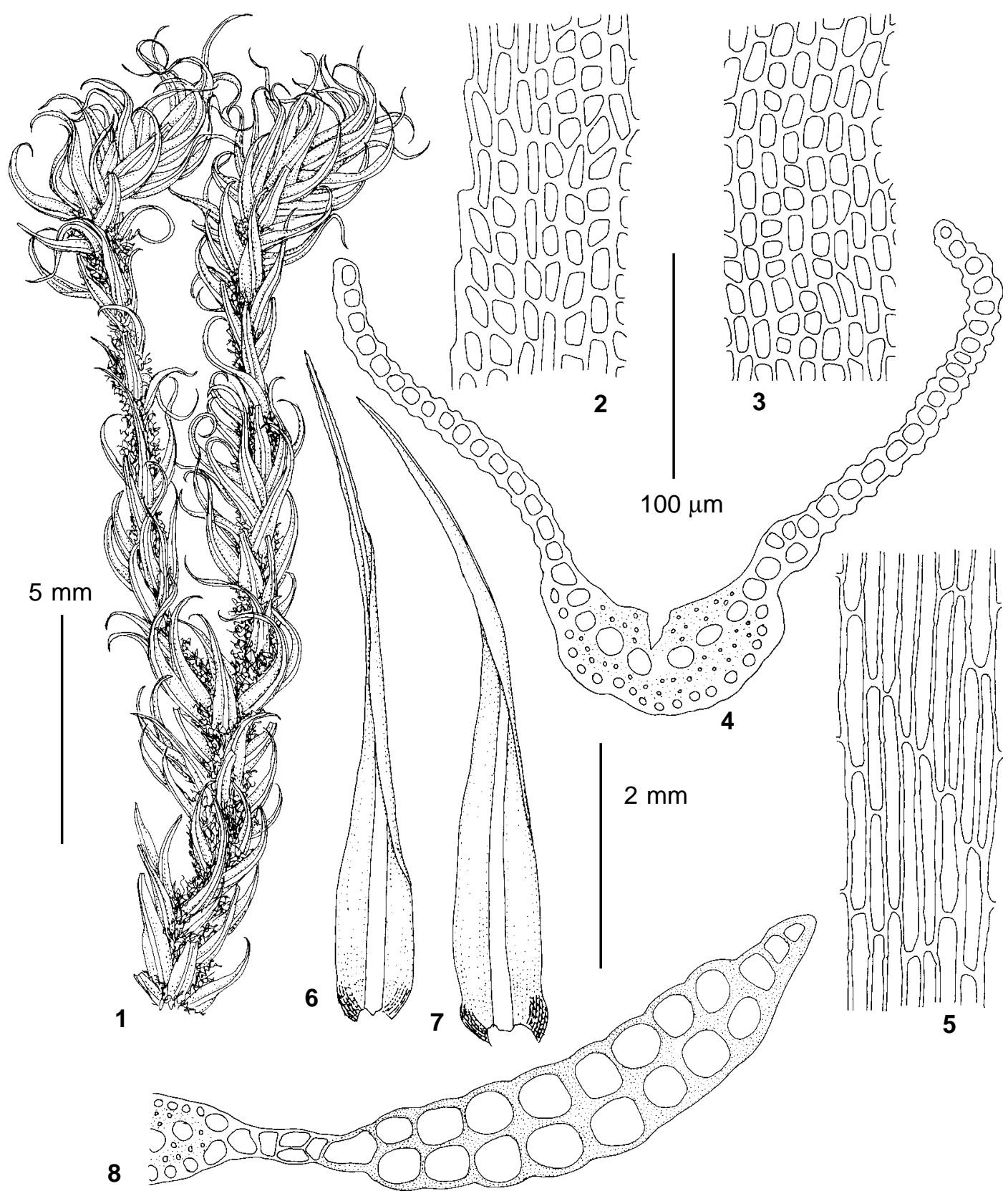

Fig. 9. Dicranum septentrionale sp. nov. (from holotype); 1 - habit, dry; 2 - upper lamina cells; 3 - median lamina cells; 4 - leaf transverse section; 5 - basal lamina cells; 6-7 - leaves; 8 - transverse section of alar region. Scale bars: $5 \mathrm{~mm}$ for $1 ; 2 \mathrm{~mm}$ for $6-7 ; 100 \mu \mathrm{m}$ for $2-5,8$.

tentrionale are curled or crisped when dry whereas they are mostly almost straight or slightly bent in D. acutifolium. Dicranum brevifolium is more similar in appearance, but it is distinct in predominantly isodiametric distal and median lamina cells and usually shorter basal cells (cf. Figs. 3-5).
Ecology. The species grows mostly in mountains from foothills to $1330 \mathrm{~m}$, or more rarely in lowlands, on soil and rocks in birch, pine and pinelarch forests, rarely in spruce forests, in Alnus stands, different types of mountain tundra and in meadows; collected once on thermal field. 
Distribution. As it was revealed from collections in LE, MW and MHA, D. septentrionale has a wide distribution in northern Eurasia, being apparently rare in most regions, except Kamchatka, where there are numerous collections. The species occurs either in the mountains or in lowland areas with numerous rock outcrops (e.g. Pinega in Arkhangelsk Province). It occurs both in Subarctic (Chukotka, Putorana Plateau, Polar Urals, and Khibiny Mts. in Murmansk Province), as well as southwards to Primorsky Territory, north of Irkutsk Province, and mostly in mountains of the South Urals. Distribution areas of D. septentrionale and $D$. brevifolium do not strongly overlap, as the latter has a more southern distribution, except NW European Russia. Dicranum brevifoli$u m$ is rather common in Kola Peninsula where $D$. septentrionale is known only from two collections in the Khibiny Mts. On the other hand, in Kamchatka the situation is just the opposite with $D$. septentrionale being more common, while $D$. brevifolium is represented by a single collection.

Other specimens examined: EUROPEAN RUSSIA: Murmansk Province: Khibiny Mts., Tulijok River valley, s-facing slope of Kukisvumchorr Mt., 2.VIII.1930, A.A.Korchagin \& M.V. Korchagina s.n. (LE); Khibiny Mts., Loparka River valley, E- facing slope of Apatitovaya Mt., 7.VIII.1930 A.A. \& M.V. Korchaginy s.n. (LE). Karelia: Petrozavodsk District, VI.1914, Dingelshtedt s.n. (LE). Bashkortostan: Burzyan District, $2 \mathrm{~km} \mathrm{~S}$ of Magadeevo, Ignatova \#9/12 (MHA); Bashkirskyi Nature Reserve, upper course of Belaya River, South Kraka Range, 10.VIII.1945, 8.IX.1945, 14.VI. 1946, 28. IX.1946, 3.VII.1948, Selivanova-Gorodkova s.n. (LE). ASIATIC RUSSIA. Krasnoyarsk Territory: Putorana Plateau, Kapchuk Lake, 4.VII.1982, Czernyadjeva \#122 (LE); Jenisei, Dudinka, 69³5' n. lat., 30.VII.1876, Arnell s.n. (LE). Irkutsk Province: Tutura River valley, 1910, Kuznetzov \#328 (LE). KhantyMansy Autonomous District: Northern (subpolar) Urals, Lysaya Gora Mt. at right slope; of Serania-el Creek (Khulga River right tributary), ca. 480 m a.s.1., 23.IX.1949, Kuvaev \#484 (MW); Kamchatka: Elovka River, 25.VIII.2003, Czernyadjeva \#110 (LE); Ushkovskyi Volcano, Bilchenok Glacier valley, 15.VII.2003, Czernyadjeva \#9 (LE); Bystraya River basin, Uvalnaya Mt., 10.VIII.2005, Czernyadjeva \#30 (LE); Esso surroundings, Ubojnyj Creek sources, 4.VIII.2003, Czernyadjeva \#78 (LE); Klyuchevskoj Dol surroundings, 19.VIII. 2004, Czernyadjeva \#99 (LE); Ostryj Tolbachik Volcano, Vodopadnyj Creek sources, 11.VIII.2006, Czernyadjeva \#22 (LE); Alnej Mt., Kirevna River, 23.VIII.201, Czernyadjeva \#24 (LE). Chukotka: Achchen Lake surroundings, 8.VII.1970, Afonina s.n. (LE).
Primorsky Territory: Soutern Sikhote-Alin, Tskhamodynza Mt., 5.IX.1959, Ponomarenko \#372 (LE).

\section{ACKNOWLEDGEMENTS}

We are grateful to the curators of $\mathrm{H}$ and LE for the loan of specimens, to Dr. V.P. Prokhorov for the Latin diagnosis and to Dr. R. Ireland for hepful suggestions. The work was partly supported by the Biodiversity Program of RAS, RFBR grants \#\#09-04-01324 \& 08-04-98021 and by Federal program «Scientific and educational personalities of innovative Russia 2009-2013», contracts №№ 14.740.11.0165 \& 16.740.111.0177.

\section{LITERATURE CITED}

BELLOLIO-TRUCCO, G. \& R.R. IRELAND 1990. A taxonomic study of the moss genus Dicranum (Dicranaceae) in Ontario and Quebec. - Can. J. Bot. 68(4): 867-909.

CLEMENT M., D. POSADA \& K.A. CRANDALL 2000. TCS: a computer program to estimate gene genealogies. - Molec. Ecol. 9: 1657-1659.

GARDINER, A., M. IGNATOV, S. HUTTUNEN \& A. TROITSKY 2005. On resurrection of the families Pseudoleskeaceae Schimp. and Pylaisiaceae Schimp. (Musci, Hypnales). - Taxon 54: 651-663.

GOLOBOFF, P.A. 1994. NONA: A Tree Searching Program. Program and documentation. Argentina, Tucumán, published by the author.

HALL, T.A. 1999. BioEdit: a user-friendly biological sequence alignment editor and analysis program for Windows 95/98/ NT. Nucl. Acids. Symp. Ser. 41: 95-98.

HEDENÄS, L. \& I. BISANG 2004. Key to European Dicranum species. - Herzogia 17: 179-197.

[IGNATOV, M.S. \& E.A. IGNATOVA] ИГНАTOB M.C., Е.A. ИГНАТОВА 2003. Флора мхов средней части Европейской России. Т. 1. - [Bryophyte flora of Middle Part of European Russia. Vol. 1] KMK, M. [KMK, Moscow], 608 pp.

IGNATOV, M.S., O.M. AFONINA, E.A. IGNATOVA et al. 2006 [2007]. Check-list of mosses of East Europe and North Asia. - Arctoa 15: 1-130.

IGNATOVA, E.A. \& V.E. FEDOSOV 2008. Species of Dicranum (Dicranaceae, Bryophyta) with fragile leaves in Russia. - Arctoa 17: 63-83.

IRELAND, R.R. 2007. Dicranum. - In: Flora of North America. Vol. 27. Mosses, part. 1. New York, Oxford, Oxford Univ. Press: 397-420.

NIXON, K.C. 1999. Winclada (BETA) ver. 0.9.9. available at http://www.cladistics.com/about_winc.html.

OTNYUKOVA, T.N. 2007. Notes on Dicranum (Dicranaceae, Musci) in Russia. 2. Dicranum pseudacutifolium, sp. nov. from North Siberia. - Arctoa 16: 163-168.

[SAVICZ-LYUBITSKAYA, L.I. \& Z.N. SMIRNOVA] САВИЧЛЮБИЦКАЯ Л.И., 3.Н. СМИРНОВА 1970. Определитель листостебельных мхов СССР. Верхоплодные мхи. [Handbook of mosses of the USSR. The acrocarpous mosses] Л., Наука [Leningrad, Nauka], 822 pp. 